\title{
Knowledge Co-Production and Transdisciplinarity: Opening Pandora's Box
}

\author{
Marcela Brugnach 1,2,3,*(D) and Gül Özerol ${ }^{4}$ (D) \\ 1 Twente Water Centre, University of Twente, P.O. Box 217, 7500 AE Enschede, The Netherlands \\ 2 Basque Centre for Climate Change (BC3), 48940 Leioa, Spain \\ 3 IKERBASQUE, Basque Foundation for Science, 48013 Bilbao, Spain \\ 4 CSTM-Department of Technology and Governance for Sustainability, University of Twente, \\ P.O. Box 217, 7500 AE Enschede, The Netherlands; g.ozerol@utwente.nl \\ * Correspondence: marcela.brugnach@bc3research.org
}

Received: 16 August 2019; Accepted: 21 September 2019; Published: 25 September 2019

\begin{abstract}
This Special Issue aims to reflect on knowledge co-production and transdisciplinarity, exploring the mutual interaction between water governance and water research. We do so with contributions that bring examples from diverse parts of the world: Bolivia, Canada, Germany, Ghana, Namibia, the Netherlands, Palestine, and South Africa. Key insights brought by these contributions include the importance of engaging the actors from early stages of transdisciplinary research, and the need for an in-depth understanding of the diverse needs, competences, and power of actors and the water governance system in which knowledge co-production takes place. Further, several future research directions are identified, such as the examination of knowledge backgrounds according to the individual and collective thought styles of different actors. Together, the eight papers included in this Special Issue constitute a significant step toward a better understanding of knowledge co-production and transdisciplinarity, with a common thread for being reflective and clear about their complexity, and the political implications and risks they pose for inclusive, plural and just water research and governance.
\end{abstract}

Keywords: water governance; transdisciplinary water research; transdisciplinarity; knowledge creation; knowledge co-production; contextual factors

Water management and governance have become increasingly complex processes [1,2]. It is presently widely recognized that we live in an era of governance failures rather than one with a lack of technologies [3]. Amid the pressures of climate change, population growth, industrialization, and urbanization, one of the major challenges faced today by global communities is the sustainable and equitable access to water resources. This goes hand in hand with a growing awareness of the role of contexts in shaping water governance, i.e., the circumstances of localities with respect to their political, cultural, technological, ecological, and economic conditions in which water problems happen [3-5]. Such an awareness resonates with the increasing attention to integrative, inclusive, and context-sensitive governance arrangements and research in addressing water challenges.

Attempts to attend to the specificities of contexts have appeal to inter- and trans-disciplinary interactions and research through stakeholder collaboration. It has now become a common practice, or at least a rather common ideal, to look for solutions to water issues (both in terms of water governance/management and of water-related research) together with stakeholders. This is reflected in an increasing number of policies, management plans, and research programs that bring academic and non-academic actors, such as water users, managers, engineers, bureaucrats, activists, journalists, scientists, consultants, businesses, etc., in their design, implementation, and practice. Some conspicuous examples are the Water Framework Directive of the European Union and the Delta Plan for Spatial 
Adaptation of the Netherlands. The requirements of the Water Framework Directive made stakeholder participation one of the most researched themes regarding the implementation of the Directive [6].

From this perspective, science alone, and disciplinary knowledge, are deemed not sufficient to capture the complex and interdependent nature of water-related problems. Scientific objective knowledge cannot account for what happens in the ground: What is important and of value for people, what are their different goals and visions, what are their motivations for actions, what are their connections with others in making collective choices. Knowledge content is inseparable from the context and forms of production [7,8]. Beyond the ideal of neutrality and universality, scientific knowledge, and technical knowledge in particular, are enmeshed with politics and power, and so are the technological fixes thought to solve water problems (e.g., technologies of desalinization to increase water quantity, while depoliticizing the deeper problem of water scarcity and social dissent $[9,10])$. Instead, it has been suggested that a different kind of knowledge is needed, one that concerns the actors themselves, and their many different ways of experiencing and knowing water [7]. Knowledge, in this Special Issue we argued, can only be developed, and become actionable, through direct engagement with those who are invested in and affected by the problem.

The involvement of stakeholders in knowledge creation has taken diverse forms and been named differently in different contexts. Transdisciplinary research and knowledge co-production are commonly coined terms to refer to the processes of bridging knowledge among academic and non-academic actors that leads to the creation, communication, and use of blended knowledge forms [11]. The underlying rationale is that by blending world views, experiences, and values with factual knowledge forms, these processes lead to the generation of more comprehensive and inclusive understandings of water problems and to knowledge that is relevant and usable in practice. These novel forms of knowledge production are claimed to improve science-policy interaction, ultimately leading to more democratic forms of knowledge making and resource governance [12]. But, do they really do so?

Collaborative efforts of knowledge creation are not just a way of representing a plural reality, but also a way of producing it $[13,14]$. These collaborations entail as much substantial as political interactions. They are constitutive of complex relationships, and as such, subject to discrepancies, conflict, and differences happening among people [15]. Often, participating stakeholders do not agree on what problems or issues are, or on the nature of the solution [16]. The identification of what needs to be known, what type of knowledge is needed, and how this knowledge is produced and communicated can vary, and even contested, across different actor groups, reflecting institutional diversity, power asymmetries, and inequalities [7,17]. The objective of this Special Issue is to reflect on issues of knowledge co-production and transdisciplinarity, exploring the mutual interaction between water governance and water research. We do so with contributions that bring examples from diverse parts of the world: Bolivia, Canada, South Africa, Namibia, Ghana, Palestine, Germany, and The Netherlands.

We begin with the paper Discovering the Political Implications of Coproduction in Water Governance, in which Lepenies et al. [18] present a critical analysis on knowledge co-production in water governance. Carrying on a comprehensive literature review on co-production in water governance, the authors identify the various meanings associated with co-production processes in different historical traditions, and investigate their political implications along the lines of three questions: How co-production is justified, how power and responsibility are allocated, and how effective and legitimate these processes are in exerting power. Through this work, the authors demonstrate that far away of being neutral, knowledge co-production processes have tremendous political implications, which are being dismissed in current literature. Using these findings, the authors drive lessons and identify future research directions, calling for reflexive forms of governance able to question what kind, to what end, with whom, and how co-production is done.

The next paper, Transdisciplinary Research and Development Cooperation: Insight from the First Phase of the Palestinian-Dutch Academic Cooperation Programme on Water, by Özerol et al., [19] explores the integration of different types of knowledge: Academic and non-academic knowledge, and knowledge from natural sciences, social sciences, and engineering, in the development and 
implementation of international cooperation programs. Drawing on six projects implemented as part of such a program in Palestine, they examine the involvement of stakeholders throughout three stages of transdisciplinary research, namely problem definition, knowledge co-production, and knowledge application [11,20,21]. Using the data collected by a survey of project teams and the review of project and program documents, the authors analyze stakeholder involvement in the three stages. Their findings indicate that research problems and objectives were identified according to the needs of the water sector, and some of the project teams involved non-academic members. However, these commitments are not followed-up during the knowledge production and application stages. The authors refer to the power asymmetries between different types of stakeholders. Such asymmetries favor governmental organizations, who are the dominant actors of the water sector, whereas the non-governmental organizations and private companies often have little capacity and expertise to participate in research projects. The authors recommend engaging the actors starting from the early stages of transdisciplinary research, and adapting the project activities and deliverables to the needs and interests of all actors, in particular, the less powerful actors.

In Transdisciplinary Learning Communities to Involve Vulnerable Social Groups in Solving Complex Water-Related Problems in Bolivia, Agramont et al. [22] adopt a transdisciplinary research approach for addressing water-related challenges in the Katari River Basin. The authors present ongoing research, where academic and non-academic actors, from different scientific disciplines and stakeholder groups, work together to integrate their different ways of conceiving, using, valuing, and deciding on water issues. Their analysis focuses on their collaboration process, including the challenges posed by working within contexts where cultural differences, social exclusion, and vulnerable social groups exist. This experience shows that transdisciplinary learning approaches can stimulate social learning between researchers, public authorities, and other stakeholders while paying special attention to vulnerable communities; serving to better integrate water problems within their social context and to overcome governance failures.

In Problemshed or Watershed? Participatory Modeling towards IWRM in North Ghana, Dare et al. [23] reflect on an action-research project conducted over the course of three years, in White Volta River, Ghana, where they initiated a multi-level dialogue to support the implementation of the Integrated Water Resources Management policy framework. The paper works at two levels: 1. Bringing the notion of problemshed to conceptualize a shared problem definition. 2. Using models and tools as boundary objects to identify a problemshed in ways that include the perspectives brought by different stakeholders. The authors adopt a Companion Modeling (ComMod) approach, where intermediary objects and tools (agent based models, role playing models, participatory maps, etc.) are used to develop a shared level of information among participants, to create knowledge, to explore common goals, and to understand the views, interest, and rationale of opposing parties, with the progressive building of a shared representation that culminates with the eventual setting of alternative management scenarios [24]. The authors conclude that: 1 . Researchers should share a common understanding of the objectives and principles of the approach. 2. The design of tools should be tailored to the needs and diversity of actors. 3. A problemshed should be identified through the participatory process rather than a pre-given problem definition.

In Shifting the Framework of Canadian Water Governance through Indigenous Research Methods: Acknowledging the Past with an Eye on the Future, Arsenault et al. [25] emphasize the importance of Indigenous knowledge systems in improving water governance practices. They develop a theoretical framework for understanding Indigenous water relations and apply Indigenous research methodologies to inform water governance frameworks, drawing on three cases regarding the First Nations water crisis in Canada. The methods and empirical findings draw on a community-based research initiative that applies decolonizing methodologies [26]. These methodologies rely on Indigenous knowledge systems, avoiding an integration process that tends to favor Western ontologies and epistemologies, and on the involvement of Indigenous and non-Indigenous scholars and practitioners. A common goal pursued in these methodologies, as also demonstrated by the three cases, is 'reciprocal learning,' 
which implies that the different actors involved in the knowledge production process learn from each other and from their relations with water.

In The Story of Water in Windhoek: A Narrative Approach to Interpreting a Transdisciplinary Process, Scott et al. [27] apply a narrative approach to analyze 'the story' of the 2015-2017 drought in Windhoek, Namibia, within the context of climate change. The authors use the empirical material from a transdisciplinary workshop that was organized as part of a larger research program to facilitate the co-production of the story. By examining the process and results of the workshop, the authors provide insights on both dimensions. The narrative approach creates a storyline that simplifies a complex institutional structure, demonstrating how the lack of decentralization of power and resources exacerbate the local water crisis and hamper climate adaptation, despite a proactive and innovative municipality. The authors also draw attention to the challenges of applying a narrative approach for knowledge co-production. A logistical challenge is that the process requires significant time and resource investment, as many participants have to come from different locations. More importantly, the authors observe that the participatory, collaborative approach to building a narrative might imply that powerful actors shape the storyline of the narrative by dominating the discussions. Similar to Özerol et al. [19], Scott et al. [27] also caution against perpetuating power asymmetries among different stakeholders and recommend future research to reveal and counter such power asymmetries starting from the design of the knowledge co-production process.

In Knowing Me, Knowing You-Capturing Different Knowledge Systems for river Landscape Planning and Governance, Henze et al. [28] identify and compare the interests of actors involved in a transdisciplinary process. Their motivation is to improve the understanding of the conflict or convergence of stakeholders' interests, which they deem critical for the design and implementation of transdisciplinary research. For this purpose, they adopt the theory of 'thought styles,' developed by Fleck in the 1940s [29]. This theory postulates that thought styles develop as a result of a socialization process in closed communities, who form 'thought collectives' based on common values, beliefs, and visions. The authors apply this theory to analyze the interests of the different actors involved, drawing on a case from river landscape development in Germany. Based on the data collected by participatory observation during actors' meetings, individual interviews, and a focus group discussion, the authors discern conflicts between the actors' perspectives regarding navigation and nature conservation, whereas potential issues for convergence include ecological river restoration and enhancing recreation. Key challenges faced by the actors during the knowledge production are the incorporation of various institutions across sectors and governance levels, and the reconciliation of different competences and responsibilities. The authors suggest future research to examine knowledge backgrounds according to the individual and collective thought styles of the participants from different sectors and governance levels, starting from the early stages of the transdisciplinary processes.

In the last paper, Informal Settlements and Flooding: Identifying Strengths and Weaknesses in Local Governance for Water Management, Williams et al. [30] work at the interface between climate change and governance in urban environments, in the assessment of informal settlements for effecting change. Specifically, they address flood risk governance in Palmier Rehabilitation Project Quarry Road West, in Durban, South Africa. Using the capital framework approach [31,32] to assess governance, they connect the effects of climate change in floods. They claim that effective governance depends upon the involvement of a diverse range of stakeholders in participatory governance processes to co-produce knowledge, and the integration of mutually constructed social values, moral beliefs, and principles ensuring the sustainable continuation of society. They conclude that a deeper understanding of governance can lead to a better embedding of social values, improving the coping capacity of (elevated) flood risks.

We believe that the insights created by the eight papers included in this Special Issue constitute a significant step toward a better understanding of knowledge co-production and transdisciplinarity, and their assumptions, both conceptually and in practice. As a modest attempt to be reflective and 
clear about the complexity that underlies these political processes, and the implications and risks they pose for inclusive, plural and just water research and governance.

Acknowledgments: We thank all authors and reviewers for their contributions and comments, as well as the WATER editorial team at MDPI for their support. This research is supported by the Spanish Government through María de Maeztu excellence accreditation 2018-2022 (Ref. MDM-2017-0714) of BC3.

Conflicts of Interest: The authors declare no conflict of interest.

\section{References}

1. Edelenbos, J.; Meerkerk, V.I.; van Leeuwen, C. Vitality of complex water governance systems: Condition and evolution. J. Environ. Policy Plan. 2015, 17, 237-261. [CrossRef]

2. Moore, M.L. Perspectives of complexity in water governance: Local experiences of global trends. Water Altern. 2013, 6, 487-505.

3. Pahl-Wostl, C. A conceptual framework for analysing adaptive capacity and multi-level learning processes in resource governance regimes. Glob. Environ. Change 2009, 19, 354-365. [CrossRef]

4. Ingram, H. Beyond Universal Remedies for Good Water Governance: A Political and Contextual Approach. Paper Presented at the Rosenberg Forum VI, Zaragoza, Spain, 25-27 June 2008.

5. Pahl-Wostl, C. Water Governance in the Face of Global Change: From Understanding to Transformation; Springer: London, UK, 2015.

6. Boeuf, B.; Fritsch, O. Studying the implementation of the Water Framework Directive in Europe: A meta-analysis of 89 journal articles. Ecol. Soc. 2016, 21, 19. [CrossRef]

7. Brugnach, M.; Ingram, H. Ways of knowing and the co-production of blended knowledge. In Science and Scientists in the Contemporary Policy Process: Changing Context, Changing Science and the Challenge of Science Impact; Weber, E., Lach, D., Steel, B., Eds.; Oregon State University Press: Corvallis, OR, USA, 2017.

8. Menga, F.; Swyngedouw, E. Water, Technology and the Nation-State; Routledge: Abingdon, UK, 2018; p. 226.

9. Swyngedouw, E.; Williams, J. From Spain's hydro-deadlock to the desalination fix. Water Int. 2016, 41, 54-73. [CrossRef]

10. Yoon, H.; Sauri, D.; Rico Amorós, A. Shifting scarcities? The energy intensity of water supply alternatives in the mass tourist resort of Benidorm, Spain. Sustainability 2018, 10, 824. [CrossRef]

11. Mauser, W.; Klepper, G.; Rice, M.; Schmalzbauer, B.S.; Hackmann, H.; Leemans, R.; Moore, H. Transdisciplinary global change research: The co-creation of knowledge for sustainability. Curr. Opin. Environ. Sustain. 2013, 5, 420-431. [CrossRef]

12. Finewood, M.H.; Holifield, R. Critical approaches to urban water governance: From critique to justice, democracy, and transdisciplinary collaboration. WIREs Water 2015, 2, 85-96. [CrossRef]

13. Bremer, S.; Meisch, S. Co-production in climate change research: Reviewing different perspectives. Wiley Interdiscip. Rev. Clim. Chang. 2017, 8, e482. [CrossRef]

14. Miller, C.; Wyborn, C. Co-production in global sustainability: Histories and theoriesv. Environ. Sci. Policy 2018. [CrossRef]

15. Brugnach, M. The space in between: Where multiple ways of knowing in water management meet. Special Issue on Helen Ingram's contributions to water, environment, and policy scholarship. J. Southwest 2017, 59, 34-59. [CrossRef]

16. Brugnach, M.; Ingram, H. Ambiguity: The challenges of knowing and deciding together. Environ. Sci. and Policy 2012, 15, 60-71. [CrossRef]

17. Lemos, M.C.; Arnott, J.C.; Ardoin, N.M.; Baja, K.; Bednarek, A.T.; Dewulf, A.; Fieseler, C.; Goodrich, K.A.; Jagannathan, K.; Klenk, N.; et al. To co-produce or not to co-produce. Nat. Sustain. 2018, 1, 722-724. [CrossRef]

18. Lepenies, R.; Hüesker, F.; Beck, S.; Brugnach, M. Discovering the political implications of coproduction in water governance. Water 2018, 10, 1475. [CrossRef]

19. Özerol, G.; Schillinger, J.; Abu-Madi, M. Transdisciplinary research and development cooperation: Insights from the first phase of the Palestinian-Dutch academic cooperation programme on water. Water 2018, 10, 1449. [CrossRef] 
20. Jahn, T.; Bergmann, M.; Keil, F. Transdisciplinarity: Between mainstreaming and marginalization. Ecol. Econ. 2012, 79, 1-10. [CrossRef]

21. Lang, D.J.; Wiek, A.; Bergmann, M.; Stauffacher, M.; Martens, P.; Moll, P.; Swilling, M.; Thomas, C.J. Transdisciplinary research in sustainability science: Practice, principles, and challenges. Sustain. Sci. 2012, 7, 25-43. [CrossRef]

22. Agramont, A.; Craps, M.; Balderrama, M.; Huysmans, M. Transdisciplinary learning communities to involve vulnerable social groups in solving complex water-related problems in Bolivia. Water 2019, 11, 385. [CrossRef]

23. Daré, W.; Venot, J.-P.; Le Page, C.; Aduna, A. Problemshed or watershed? Participatory modeling towards IWRM in North Ghana. Water 2018, 10, 721. [CrossRef]

24. Etienne, M. Companion Modelling: A Participatory Approach to Support Sustainable Development; Étienne, M., Ed.; Springer: Dordrecht, The Netherlands, 2014.

25. Arsenault, R.S.; Diver, D.; McGregor, A.; Witham, C. Bourassa. 2018. Shifting the framework of Canadian water governance through indigenous research methods: Acknowledging the past with an eye on the future. Water 2018, 10, 49. [CrossRef]

26. Smith, L.T. Decolonizing Methodologies: Research and Indigenous Peoples; Zed Books: London, UK, 2012; ISBN 978-1-84813-950-3.

27. Scott, D.; lipinge, K.N.; Mfune, J.K.E.; Muchadenyika, D.; Makuti, O.V.; Ziervogel, G. The story of water in Windhoek: A narrative approach to interpreting a transdisciplinary process. Water 2018, 10, 1366. [CrossRef]

28. Henze, J.; Schröter, B.; Albert, C. Knowing me, knowing you-Capturing different knowledge systems for river landscape planning and governance. Water 2018, 10, 934. [CrossRef]

29. Cohen, R.; Schnelle, T. Cognition and Fact_Materials on Ludwik Fleck; Boston Studies in the Philosophy and History of Science; Springer: Dordrecht, The Netherlands, 1986.

30. Williams, D.S.; Máñez Costa, M.; Celliers, L.; Sutherland, C. Informal settlements and flooding: Identifying strengths and weaknesses in local governance for water management. Water 2018, 10, 871. [CrossRef]

31. Bebbington, A. Capitals and capabilities: A framework for analyzing peasant viability, rural livelihoods and poverty. World Dev. 1999, 27, 2021-2044. [CrossRef]

32. Máñez Costa, M.; Carmona, C.; Gerkensmeier, B. Assessing Governance Performance; Report 20; Climate Service Centre Germany: Hamburg, Germany, 2014.

(C) 2019 by the authors. Licensee MDPI, Basel, Switzerland. This article is an open access article distributed under the terms and conditions of the Creative Commons Attribution (CC BY) license (http://creativecommons.org/licenses/by/4.0/). 